\title{
Exploring nexus among sensory marketing and repurchase intention: Application of S-O-R Model
}

\author{
Selvan Perumal ${ }^{\mathrm{a}^{*}}$, Jawad Ali ${ }^{\mathrm{a}}$ and Hasnizam Shaari ${ }^{\mathrm{a}}$
}

${ }^{a}$ Universiti Utara Malaysia, Malaysia

\section{H R O N I C L E}

\section{Article history:}

Received: November 18, 2020

Received in revised format:

November 282020

Accepted: December 27, 2020

Available online:

December 27, 2020

Keywords:

Repurchase Intention

Gustatory Stimuli

Touch Stimuli

Airline Image

Airline Industry Pakistan

\section{A B S T R A C T}

The primary objective of the present research is to examine the impact of touch and gustatory stimuli on airline image and repurchase intention. Furthermore, the present research examines the moderating role of price fairness and mediation impact of airline image. The researchers gather data from the customers of PIA and Airblue travelling abroad from Islamabad International Airport, Karachi International airport and Lahore International airport by employing multi-stage sampling technique. Total of 576 questionnaires was distributed among the respondents, and the response rate was $68.9 \%$. For the analysis of data received, the researcher employed PLS-SEM. The finding of the study confirmed the significant impact of touch and gustatory stimuli on airline image and repurchase intention. Findings of the study revealed the mediating role of airline image among touch, gustatory and repurchase intention was significant as well. At the end, perceived price fairness also moderated the relationship of airline image and repurchase intention. The present study fills the gap of limited studies conducted in the past regarding sensory stimuli in the context of the airline industry, the role of airline image as a mediator under SOR model and moderating impact of perceived price. Findings of the present study are helpful for policymakers and practitioners of the airline industry in Pakistan to develop the strategy by which they can retain their customers on international routes.

\section{Introduction}

Customers are the asset for the organizations, especially in the service sector. One of the important service sector industry is the airline industry which plays a very important role for economic and social development. Its role is also very critical for the development of tourism in any country. But, the competition in the airline industry is increasing rapidly, resulting in a rise in expectations and demands of the customers. In this situation, it has become very important as well as difficult for airline companies to retain their customers. Retention of customers for the airline companies is very important to keep a stable revenue stream and market share (Chang \& Hung, 2013). The cost of attaining new customers is much higher than retention of new customers. Therefore, customers repurchase intention is the most important concern for most of organizations. Airline organizations should try to provide good in-flight experience to customers since the experience of the customer is the basic reason upon which buying the product or service from the same service provider is decided.

In order to survive in this constantly changing global market, airline operators need to find the factors by which they can retain the customers. One of the important factors which play an important role in building a positive image and retain the customers is improved flight environment, which customers experience during the flight. In-flight environment and services like the comfort of seats, refreshment, furnishing, layout, equipment, temperature and air quality are critical factors by which customer evaluate an airline and decide to reuse its services again in future (Loureiro \& Fialho, 2017). They are the factors that provide a sensory experience to the customers. Inflight environment and services are also known as atmospherics, which is the base of sensory stimuli. Among five sensory stimuli's, gustatory and touch stimuli play an important role for customers to develop a certain perception in the mind of the customer and be involved in repurchase process.

* Corresponding author.

E-mail address: selvan@uum.edu.my (S. Perumal) 
Touch is the most important and vital sensory organ of the human body. It is basically the sense which human feel through their skins. Skin covers almost every part of the human body. Therefore, its role is very important in case of sense. Sense of touch is responsible for around one-fourth of the brand-building process. Touch stimuli includes temperature, quality of air, the comfort of seats and other related stimuli factors where a customer can feel while using the services of an airline. On the other hand, gustatory stimuli are related to the sense of taste where customer experiences through food. It represents the quality, variety and taste of food that a customer experiences when a meal is presented. The taste sense of the customers is one of the most developed and important senses. Most of the taste sense of the consumer is experience-based, and once a customer accepts the flavour, it has a significant impact on the choice of the product or service (Spence \& Fiszman, 2014).

Pakistan based airlines dominated the airline industry for several years on international routes. In 2013, PIA, Air blue and Shaheen jointly shared $55 \%$ of the market share of passengers travelling abroad from Pakistan. But in the next five years, this market share dropped dramatically to $42 \%$, which is a decline of $13 \%$. This is the huge decline highlighting the issue of repurchase intention among the customers of Pakistan based airlines (Saleem, Zahra, \& Yaseen, 2017). To address the issue of repurchase intention, the present study examined the impact of touch stimuli and gustatory stimuli on airline image and customer repurchase intention in the context of Pakistan airline industry. Moreover, the study also examined the mediating role of airline image and moderating impact of perceived price fairness as well.

\section{Literature Review}

\subsection{SOR Model}

The concept of stimulus organism response model was introduced by two environmental psychologists (Mehrabian \& Russel, 1974). This model is also known as the S-O-R model. This model has three parts, Stimuli (S), Organism (O) and Response (R). This model implies that stimuli $(\mathrm{S})$ leads to perception $(\mathrm{O})$, which creates response $(\mathrm{R})$ of the customers. According to SOR model, environmental factors impact the perceptions which create the response. The response of the customer has two possible reactions, i.e. approach or avoidance.

Based on the guidelines of SOR model, the present research develops a theoretical framework in which touch and gustatory stimuli effects are the airline images which would impact repurchase intention. Moreover, airline image is used as the representation of Organism $(\mathrm{O})$ as it is the internal response of environmental stimuli. Whereas, repurchase intention is the response (R) of the SOR model representing approach reaction of the consumer. It is important to mention that, most of the studies conducted in the past have discussed organism (O) in terms of emotions as an outcome of environmental stimuli (S) including positive and negative emotions. Therefore, the present research tries to bridge this gap by using airline image as an organism (O) which is rarely used in SOR model as an organism $(\mathrm{O})$ in past studies.

\subsection{Repurchase Intention}

For the organizations operating in the service sector, customers are the most important asset. For the survival of organizations, it is key that the needs of the customers must be understood and fulfilled. By fulfilling these needs, customers can be retained by the organizations (Onyemachi \& Lilian, 2012). The profitability, as well as revenue of the organizations, are directly impacted by customer retention. In the same context, Singh and Khan (2012) mentioned that organizations could enjoy business growth, high profit and competitive advantage through customer repurchase. Additionally, for the success of the organization, retention of customers is very important. Moreover, in the present competitive era, it is critical for customers to develop repurchase intention so they can gain a competitive advantage.

In past literature, repurchase intention is defined by several authors. Jones and Taylor (2007) defined repurchase intention as customers aim to sustain the relationship with the same service provider in future. On the other hand, Bayraktar, Tatoglu, Turkyilmaz, Delen, and Zaim (2012) defined repurchase intention as the judgement of the individual in terms of purchasing a specific service repeatedly, the choice to be engaged with the same service provider in the future again. Repurchase intention in this research is defined as customers willing to travel through Pakistan based airlines on international routes.

\subsection{Airline Image}

Image is described by Cornelissen (2006) described an image as a network of a number of meanings which are stored in the memory of a person. These memories can range from holistic to translate the evaluation of any product or service. So, an image can also be defined as the impression created in the mind of the person at a certain time. Thus, the term image refers to the impression created at a particular level of abstraction and at a particular time as well. The overall impression left in the mind of the customer is the image. It is the result of experiences, ideas and feelings with a certain product or service of the organization stored in the mind of the customer. This memory is later on transformed into a negative or positive meaning which is retrieved to form an image. This image is recalled when the name of the organization is heard or seen by the customer (Bravo, Montaner, \& Pina, 2009). Therefore, in the present study, airline image is described as the perception held in the mind of the airline passengers travelling through Pakistani carriers on international destinations. 


\subsection{Touch Stimuli: Relationship with Airline Image and Repurchase Intention}

Sense of touch within a person is enabled by touching a product, object or any other person. Skin of human the largest sensory organ of the human body. The primary channel through which a person can sense the touch is the human hand. By touching the product, some information can be gathered. Positive perception and feeling regarding the product can be evoked within an individual by touching the product. Touching the product is very important for the evaluation of the product and to develop a positive perception in the mind of the customer. Customers during the buying process tend to buy the product which they are allowed to touch. Customers gather information by touching the product, which cannot be gathered through observation (Aitamer \& Zhou, 2011). All this information contributes towards the development of positive perception in the mind of customer (Erenkol \& Merve, 2015). In the context of this study, touch stimuli are defined as temperature, air quality, the comfort of seats and leg space which a passenger experience during air travel.

Touch cues play an important role to develop a perception in the mind of the customer. According to the research of Yoganathan, Osburg, and Akhtar (2019), touch cues have an impact on the perceptions of the consumers as well. In another empirical study, researchers found that the image of the airline is significantly impacted by the temperature and quality of air (Suh, Moon, Han, \& Ham, 2015).

In the study conducted by Ali, Omar, and Amin (2013) it was revealed that temperature is a touch element due to which customer may intent to revisit the resort. Additionally, Lau (2017) also affirms that touch stimuli in terms of interaction may have a significant impact on the intention of the tourists to revisit the Asian tourist spots.

Therefore, based on the above arguments, it has been hypothesized that:

$\mathrm{H}_{1}$ : Touch stimuli have a significant impact on airline image.

$\mathrm{H}_{2}$ : Touch stimuli have a significant impact on repurchase intention.

\subsection{Gustatory Stimuli: Relationship with Airline Image and Repurchase Intention}

Căruntu and Diţoiu (2014) defined gustatory as the taste and flavour of the food. In the present study, gustatory stimuli are defined in terms of the taste of the food provided to passengers travelling through Pakistan based airlines. Within the sense of taste, there are five basic senses, namely, sweet, salty, savoury, sour and bitter. Most specific function to any of five human senses is provided by the sense of taste. The sense of taste plays a critical role in creating the perception of the brand and altering the mood of the customers (Căruntu \& Diţoiu, 2014; Lindstrom, 2005).

Moving toward the empirical evidence between taste stimuli and Image, Hussain (2018), in his research, revealed that the taste of food had a positive impact on the brand image. In the same context, Lau (2017) also mentioned the same results in his research that variety of food had a significant impact on destination image.

In terms of the relationship among gustatory stimuli and repurchase intention, Liu and Jang (2009) mentioned that taste, quality and freshness of food are a few of important factors in Chinese restaurants to have an impacted intention to revisit. In the context of the airline industry, of the outcomes of in-flight service attributes, Zahari, Salleh, Kamaruddin, and Kutut (2011) found that airline meals (variety, hygiene, and freshness) significantly influence air travellers' intention to reuse the airline. Thus, we hypothesized that

$\mathrm{H}_{3}$ : Gustatory stimuli have a significant impact on airline image.

$\mathrm{H}_{4}$ : Gustatory stimuli significantly impacts repurchase intention.

\subsection{Airline image and Repurchase Intention}

While discussing the important factors of the repurchase intention, image of the firm in a different context has played an important role in order to influence the repurchase intention of the customers (Saleem et al., 2017). A positive image of the brand generates trust among the customers. Furthermore, the positive image of the brand will also have a positive impact on repurchase (Park, Robertson, \& Wu, 2004). Moreover, Hu, Kandampully, and Juwaheer (2009) found that in tourism industry positive image is an important factor for the tourist to repurchase. In the context of airlines, Park et al. (2004) found that the customers who had a positive image of the airlines were more likely to use the services of the airlines again. Same results were found by Geraldine (2013) that among airline customers, airline image has a positive relationship with the passenger's repeat purchase.

$\mathrm{H}_{5}$ : Airline Image has a significant impact on repurchase intention.

\subsection{Airline Image as Mediator}

As mentioned earlier, touching a product plays an important role on the perception of consumers and is especially important at the stage of product assessment. It is important to mention that when a customer sees a product, he or she comes near it to 
touch it, which has an impact on its perception. Moreover, according to Keller (1993), the image in the mind of the customer is the perception developed in the mind of the customer. Moreover, Park et al. (2004) found a positive relationship between image and repurchase intention. Ali et al. (2013) also mentioned that temperature is one of the important factors in creating an image of the resort. It has been revealed that temperature is a touch element due to which customer may intent to revisit the resort.

In the context of gustatory stimuli, Kim, Galliers, Shin, Ryoo, and Kim (2012) found that food quality, including the taste, freshness and deliciousness has a significant impact on restaurant image. In the same vein, Zahari et al. (2011) found that meals provided by (variety, hygiene, and freshness) significantly influence air travellers' intention to reuse the airline.

$\mathrm{H}_{6}$ : Airline image mediates significantly between touch stimuli and repurchase intention.

$\mathrm{H}_{7}$ : Airline image mediates significantly among gustatory stimuli and repurchase intention

\section{Perceived Price Perception: Role as Moderator}

The success or failure of the organization is mainly dependent on the price factor, which eventually impacts the profitability of the firm. Price is defined by Kotler and Armstrong (2010) as the amount charged from the customer by the organization against the services provided or purchase of the product. In other words, it is the total of value which is exchanged by the customer in order to use a service or purchase a product.

Repurchase interest of the customer is significantly affected by price perception. Customers will evaluate the price in a positive manner and develop positive price perception as a result of the evaluation of price comparison with the same products or services is according to the wishes of the customers. An increase in the perception of a positive price the consumer has for a product will increase interest in repurchasing (Liu \& Lee, 2016).

On the other hand, there is an inconsistent relationship between the airline image and repurchase intention, which shows that there is a need for some moderating variable on this path. Moreover, on the recommendations of Ryu and Han (2010), moderating role of PPF will be examined on the path of airline image and repurchase intention.

$\mathrm{H}_{8}$ : Perceived price fairness moderates the relationship of airline image and repurchase intention.

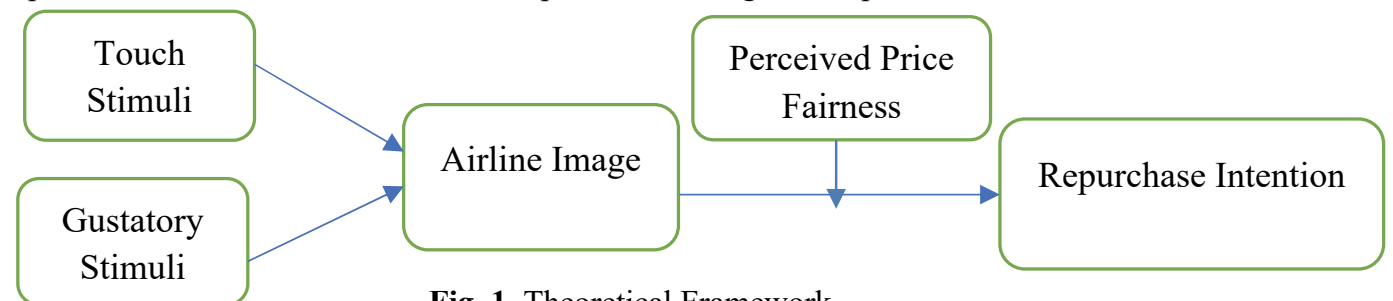

Fig. 1. Theoretical Framework

\section{Methodology}

The data was collected by the researcher from the airports of Karachi, Lahore and Islamabad. The items of the questionnaires were adapted from past studies. All items of questionnaires were measured using a 7-point Likert scale ranging from 1 (Strong disagree) to 7 (Strongly agree). The researcher conducted pre-testing involving content validity and pilot testing before the collection of data. The Cronbach alpha of all the variables was above the benchmark of 0.70 . The finalized version of the questionnaire was distributed among 576 passengers travelling abroad from Karachi, Lahore and Islamabad International airport. The researcher adopted a judgemental sampling technique for the collection of data. The questionnaire was distributed personally to international passengers and collected later as well. From 576 distributed questionnaires, 421 questionnaires were received back, out of which 397 questionnaires were usable for the analysis of data having the response rate of $68.92 \%$. The researcher used PLS-SEM for the analysis of the data. Repurchase intention in the present study was measured using five items adapted from Şahin, Zehir, and Kitapccedil (2012), airline image was measured through four items adopted by Singh (2015), Gustatory stimuli and touch stimuli were measured through seven and five items respectively adopted from Wiedmann, Labenz, Haase, and Hennigs (2018) and five items of perceived price fairness were measured from (Estalami, Maxwell, Martín-Consuegra, Molina, \& Esteban, 2007).

\section{Results}

The results of the data collected were analysed by using Partial Least Square (PLS) 3.3.2 and SPSS 25. In the beginning, data screening, including missing values, outliers and multicollinearity, was assessed using SPSS 25. Later, results were gathered through the measurement model of PLS and structural model representing the structural paths hypothesized in the study. In the end, the moderating impact of moderating variables is also examined and elaborated through the structural model. 
At the beginning of the analysis, the researcher used SPSS 25 to find the demographics of the study. Fig. 1 below shows the demographic profile of the respondents. Most of the respondents travelling abroad were male, $73.3 \%$ where more than $26.7 \%$ were women. Among these respondents, more than $81 \%$ of the respondents were married, whereas above $17 \%$ figure represents the non-married respondents. As far as the age of respondents is a concern, more than $65 \%$ of the respondents fall under the category of 20 years to 40 years of age.

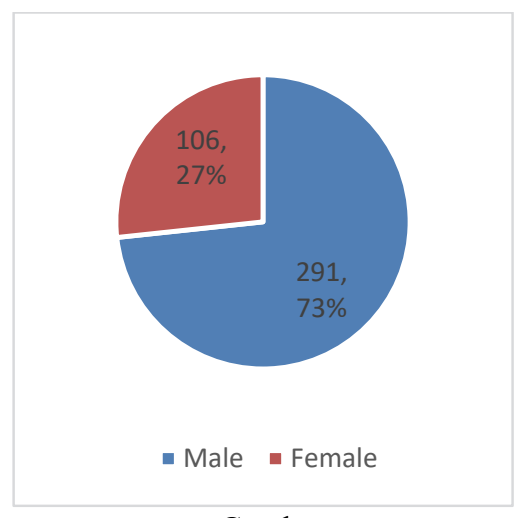

Gender

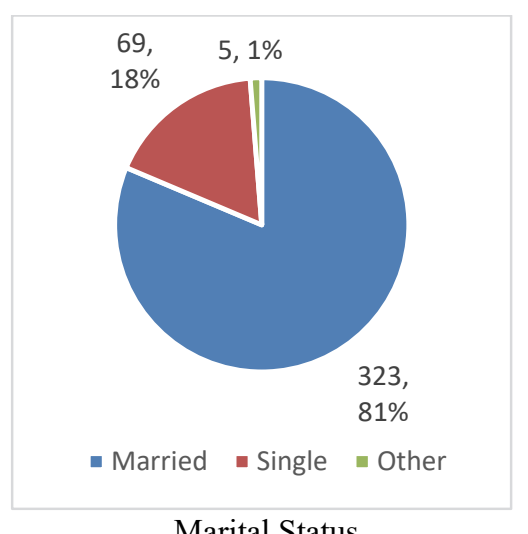

Marital Status

Fig. 1. Demographics

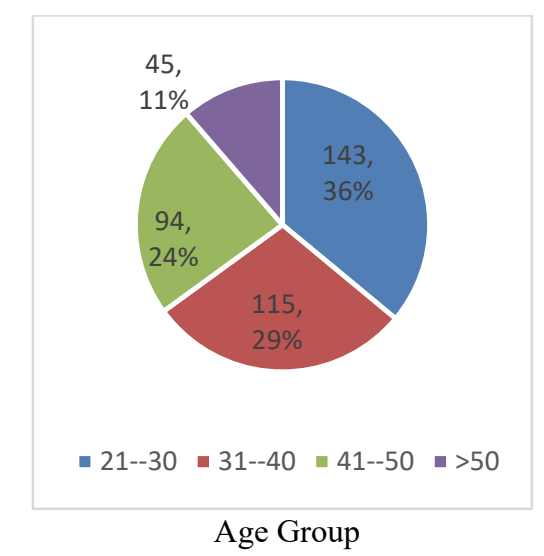

Age Group

After gathering information regarding demographics, the researcher removed missing values from the data by using the estimation maximization approach (Schlomer, Bauman, \& Card, 2010). Later, Mahala Nobis (D2) test was done to point out the outliers in the present study. SPSS 25 was used to calculate the D2. One outlier was detected and removed from data. Remaining 396 values were used for analysis through PLS at the next stage. Data analysis through PLS consists of two steps, i.e. measurement model and structural model (Hair, Sarstedt, Ringle, \& Gudergan, 2017). The first step is the assessment of the measurement model, which consist of internal consistency and reliability of individual items. It also includes the assessment of the measurement model, which further consist of two types, namely discriminant validity and convergent validity. At the second step, a structural model is assessed which include assessing the significance of path coefficient, R squared, effect size, $\mathrm{Q}^{2}$ which is the construct cross-validated redundancy, moderation effect and hypothesis testing which include both direct and indirect hypothesis (Kashif, Zarkada, \& Ramayah, 2018). Before implying the measurement model through PLS, the researcher calculated VIF to assess the multicollinearity of the items. Tabachnick, Fidell, and Ullman (2007) defined multicollinearity as "the problems with a correlation matrix that occurs when variables are too highly correlated. Smart PLS was used to calculate the VIF of the variables of the study. Studies have mentioned that the maximum value of VIF must not go above 5. Table 1 below shows all values meeting the requirements of VIF.

Table 1

Variance Inflation Factors (VIF)

\begin{tabular}{lcc}
\hline & AI & RPI \\
\hline AI & 1.042 & 1.459 \\
GUST & 1.042 & 1.248 \\
PPF & 1.338 \\
TCH & 1.238 \\
\hline Note: AI= Airline Image, RPI= Repurchase Intention, TCH= Touch Stimuli, GUST= Gustatory Stimuli, PPF = perceived price fairness
\end{tabular}

Later, the researcher assessed the measurement model through PLS. As per the first step of the measurement model, reliability and convergent validity are assessed. For the assessment of convergent validity, average variance extracted, and factor loading was assessed. As the criteria proposed by the researchers, convergent validity is attained if the factor loading of every item of the study is more than 0.70 . Moreover, Hair et al. (2017) pointed out that the items retained in the study should have the loading of more than 0.708 . Following these two mentioned criteria, two items namely PPF 4 and GUST 7, were deleting having factor loading less than 0.708. Researcher in the present study followed the criteria mentioned by Hair, Sarstedt, Ringle, and Mena (2012) to calculate AVE and to the attainment of convergent validity. The recommended value of AVE should be 0.5 or above in order to ascertain convergent validity (Hair et al., 2012). As a result, table 3 below shows that the values of AVE are above 0.5 .

The next stage is to calculate the internal consistency of the items of variables of the study. McCrae, Kurtz, Yamagata, and Terracciano (2011) explained internal consistency reliability as the level to which all items of certain subscale measures the same concept. For the internal consistency, a researcher in the present study composite reliability CR and calculated Cronbach alpha $(\alpha)$. As per the criteria pointed out by George and Mallery (2003), the values above $0.7,0.8$ and 0.9 are classified as acceptable, good and excellent respectively whereas 0.70 is the benchmark for the acceptability of CR and Cronbach Alpha. Table 2 below shows these criteria is fulfilled as well 
Table 2

Factor loading and internal consistency

\begin{tabular}{|c|c|c|c|c|c|}
\hline Construct & Items & Loading & Cronbach's Alpha & CR & AVE \\
\hline \multirow{5}{*}{ Touch Stimuli } & TCH1 & 0.839 & \multirow[t]{5}{*}{0.865} & \multirow[t]{5}{*}{0.903} & \multirow[t]{5}{*}{0.650} \\
\hline & $\mathrm{TCH} 2$ & 0.827 & & & \\
\hline & TCH3 & 0.830 & & & \\
\hline & TCH4 & 0.775 & & & \\
\hline & TCH5 & 0.757 & & & \\
\hline \multirow{6}{*}{ Gustatory Stimuli } & GUST1 & 0.760 & \multirow[t]{6}{*}{0.855} & \multirow[t]{6}{*}{0.892} & \multirow[t]{6}{*}{0.580} \\
\hline & GUST2 & 0.800 & & & \\
\hline & GUST3 & 0.785 & & & \\
\hline & GUST4 & 0.713 & & & \\
\hline & GUST5 & 0.720 & & & \\
\hline & GUST6 & 0.788 & & & \\
\hline \multirow[t]{4}{*}{ Airline Image } & AI1 & 0.880 & \multirow[t]{4}{*}{0.870} & \multirow[t]{4}{*}{0.911} & \multirow[t]{4}{*}{0.719} \\
\hline & $\mathrm{AI} 2$ & 0.819 & & & \\
\hline & $\mathrm{AI} 3$ & 0.862 & & & \\
\hline & $\mathrm{AI} 4$ & 0.830 & & & \\
\hline \multirow[t]{6}{*}{ Repurchase Intention } & RPI1 & 0.853 & \multirow[t]{5}{*}{0.891} & \multirow[t]{5}{*}{0.920} & \multirow[t]{5}{*}{0.696} \\
\hline & RPI2 & 0.835 & & & \\
\hline & RPI3 & 0.834 & & & \\
\hline & RPI4 & 0.833 & & & \\
\hline & RPI5 & 0.816 & & & \\
\hline & PPF1 & 0.711 & \multirow[t]{4}{*}{0.790} & \multirow[t]{4}{*}{0.863} & \multirow[t]{4}{*}{0.612} \\
\hline \multirow[t]{3}{*}{ Perceived Price Fairness } & PPF2 & 0.831 & & & \\
\hline & PPF3 & 0.827 & & & \\
\hline & PPF5 & 0.755 & & & \\
\hline
\end{tabular}

Note: $A I=$ Airline Image, $R P I=$ Repurchase Intention, $T C H=$ Touch Stimuli, GUST = Gustatory Stimuli, $P P F=$ perceived price fairness

Later, discriminant validity was calculated through Heterotrait-Monotrait ratio of correlation (HTMT) criteria. Basically, discriminant validity is the level at which a certain latent variable varies from the remaining latent variables (Farrell \& Rudd, 2009). Basically, HTMT is the method which is newly developed for PLS-SEM in order to evaluate discriminant validity. The HTMT criteria outclass the past approach significantly in order to determine discriminant validity, i.e. cross-loadings (Fornell \& Larcker, 1981). PLS algorithm procedure was used in order to evaluate HTMT. The values obtained were less than 0.85 showing all constructs meet the discriminant validity. Table 3 below shows the discriminant validity through HTMT.

Table 3

Discriminant Validity (HTMT)

\begin{tabular}{|c|c|c|c|c|c|}
\hline & AI & GUST & PPF & RPI & TCH \\
\hline \multicolumn{6}{|l|}{ AI } \\
\hline GUST & 0.489 & & & & \\
\hline PPF & 0.515 & 0.367 & & & \\
\hline RPI & 0.577 & 0.424 & 0.574 & & \\
\hline ТСH & 0.418 & 0.233 & 0.444 & 0.525 & \\
\hline
\end{tabular}

Assessment of structural model is the next phase after assessment of measurement model to test the direct as well as the indirect hypothesis of the study. In the same context, it has been pointed out by Sarstedt, Ringle, Henseler, and Hair (2014), the structural model deals with structural relationships hypothesized in a research model. Bootstrapping and PLS algorithm were used in order to assess the structural model. Keeping in view the recommendations of Chin (2010), the procedure of standard bootstrapping was adopted with 5000 bootstrap samples. For this purpose, data of 396 cases were used to examine the path coefficient significance. The proposed hypothesis in the present study are two-tailed; therefore, cut offline of t-value to accept the hypothesis is 1.967 (Sarstedt et al., 2014). Direct relationships of the present study are mentioned in the table below.

Table 4

Direct Results

\begin{tabular}{|c|c|c|c|c|c|c|}
\hline HYP & Path & Beta & SD & T Value & P Values & Decision \\
\hline H1 & $\mathrm{TCH} \rightarrow \mathrm{AI}$ & 0.289 & 0.051 & 5.690 & 0.000 & Accepted \\
\hline H2 & $\mathrm{TCH} \rightarrow \mathrm{RPI}$ & 0.242 & 0.051 & 4.725 & 0.000 & Accepted \\
\hline H3 & GUST $\rightarrow$ AI & 0.368 & 0.054 & 6.857 & 0.000 & Accepted \\
\hline H4 & GUST $\rightarrow$ RPI & 0.161 & 0.048 & 3.367 & 0.001 & Accepted \\
\hline H5 & $\mathrm{AI} \rightarrow \mathrm{RPI}$ & 0.284 & 0.060 & 4.777 & 0.000 & Accepted \\
\hline
\end{tabular}

Note: $A I=$ Airline Image, $R P I=$ Repurchase Intention, $T C H=$ Touch Stimuli, $G U S T=$ Gustatory Stimuli, $P P F=$ perceived price fairness, $B=$ Beta

The findings of the study show there are some significant and positive relationships among all proposed direct hypotheses. According to Table $4, \mathrm{H}_{1}$ is accepted $(\mathrm{B}=0.289$, $\mathrm{t}$-value $=5.690$, $\mathrm{p}$-value $=0.000), \mathrm{H}_{2}$ is accepted statistically $(\mathrm{B}=0.242, \mathrm{t}-$ value $=4.725$, $\mathrm{p}$-value $=0.000), \mathrm{H}_{3}$ is also accepted $(\mathrm{B}=0.368, \mathrm{t}$-value $=6.857, \mathrm{p}$-value $=0.000), \mathrm{H}_{4}$ is accepted $(\mathrm{B}=0.161, \mathrm{t}-$ value $=3.367$, $\mathrm{p}$-value $=0.001)$, and $\mathrm{H}_{5}$ is accepted as well $(\mathrm{B}=0.284$, $\mathrm{t}$-value $=2.249$, $\mathrm{p}$-value $=0.000)$. 
Table 5

Mediation Results

\begin{tabular}{|c|c|c|c|c|c|c|}
\hline HYP & Path & Beta & STDEV & T-value & P Values & Decision \\
\hline H6 & $\mathrm{TCH} \rightarrow \mathrm{AI} \rightarrow \mathrm{RPI}$ & 0.082 & 0.024 & 3.386 & 0.001 & Supported \\
\hline H7 & GUST $\rightarrow$ AI $\rightarrow$ RPI & 0.105 & 0.028 & 3.686 & 0.000 & Supported \\
\hline
\end{tabular}

Later, mediation results were also calculated and found significant as well. Mediation results pointed out that airline image mediates the relationship between touch stimuli and repurchase intention $(B=0.082 \mathrm{t}$-value $=3.386$, $\mathrm{p}$-value $=0.001)$, whereas airline image also mediates significantly the relationship between gustatory stimuli and repurchase intention $(B=0.105$, $t-$ value $=3.686$, $p$-value $=0.000$ ). In the end, moderation results were calculated through the structural model in the present study. The findings of the moderation hypothesis are mentioned in Table 6 and Fig. 2 below. The findings of the study show that perceived price fairness moderates significantly the path of airline image and repurchase intention $(B=0.102, t-v a l u e=2.249$, p-value $=0.025$ ).

Table 6

Moderation Result

\begin{tabular}{llccccl}
\hline HYP & Path & Beta & (STDEV) & T Value & P-Value & Decision \\
\hline $\mathrm{H} 8$ & AI $\times$ PPF $\rightarrow$ RPI & 0.102 & 0.045 & 2.249 & 0.025 & Supported \\
\hline
\end{tabular}

Note: $A I=$ Airline Image, $R P I=$ Repurchase Intention, $P P F=$ perceived price fairness

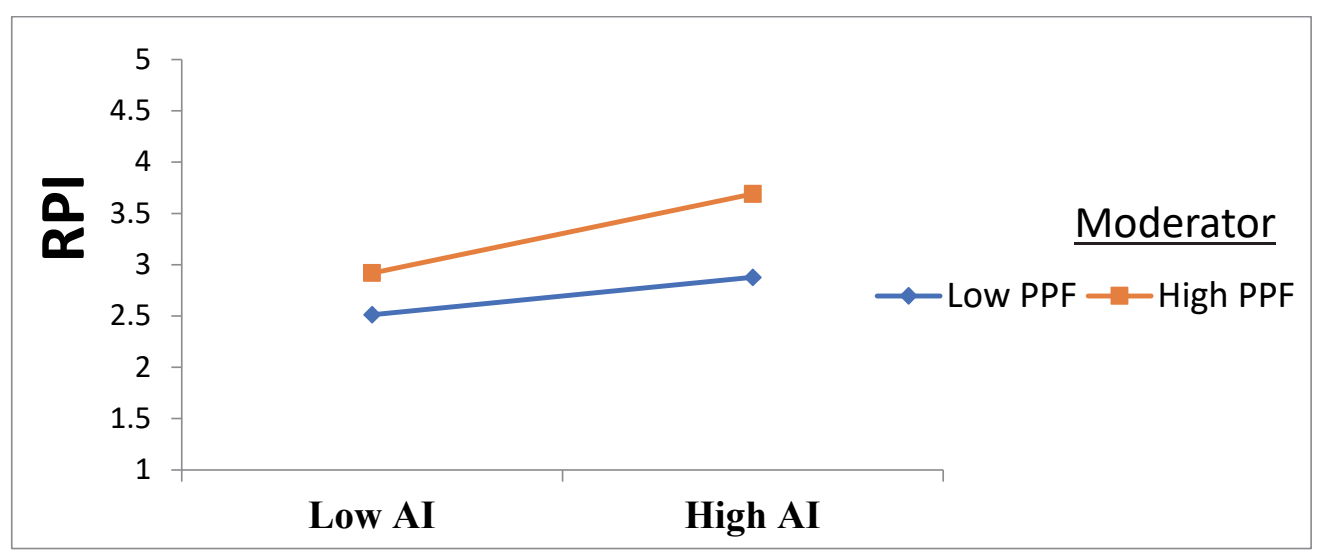

Fig. 3. Moderation Impact

Note: $\mathrm{AI}=$ Airline Image, $\mathrm{RPI}=$ Repurchase Intention, $\mathrm{PPF}=$ perceived price fairness

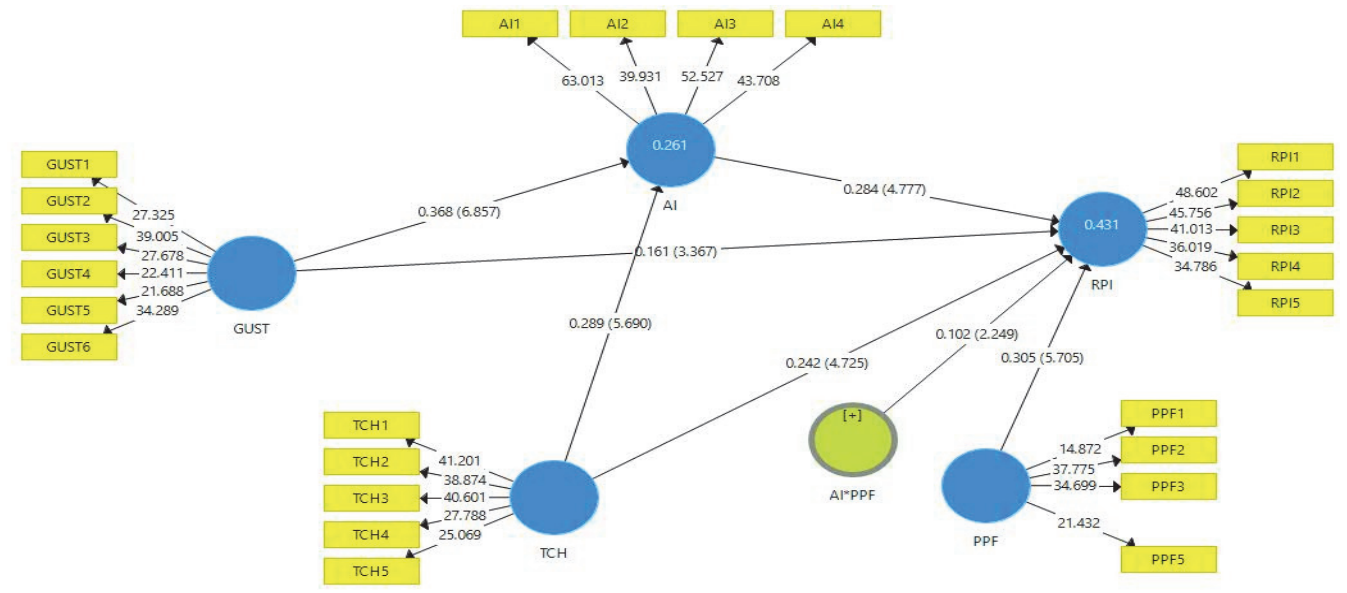

Fig. 4. Structural Model

Note: $A I=$ Airline Image, $R P I=$ Repurchase Intention, $T C H=$ Touch Stimuli, GUST= Gustatory Stimuli, $P P F=$ perceived price fairness

Coefficient of determination $\left(\mathrm{R}^{2}\right)$ of the endogenous constructs was used in this study in order to predict the power of the structural model (Chin, 2010). According to Cohen (1988), the $\mathrm{R}^{2}$ value equal to 0.02 is considered as weak, 0.13 as moderate and 0.26 as substantial. Table 8 shows the coefficient of determination of the present study. Later effect size (F square) of each variable on outcome variables was measured as well. The criteria of $\mathrm{f}^{2}$ was established by Cohen (1988) according to 
which 0.02 is considered as small effect size, 0.15 is considered as medium and 0.35 as substantial effect size. Table 8 shows the values of the effect size of the present study.

Table 7

R Square

Construct

Repurchase Intention R Square

Airline Image

0.261

0.431

Table 8

F Square

\begin{tabular}{lcc}
\hline & AI & RPI \\
\hline AI & & 0.091 \\
AI $\times$ PPF & & 0.016 \\
GUST & 0.176 & 0.035 \\
PPF & & 0.098 \\
TCH & 0.108 & 0.083 \\
\hline Note: AI= Airline Image, RPI= Repurchase Intention, TCH= Touch Stimuli, GUST= Gustatory Stimuli, PPF= perceived price fairness
\end{tabular}

In the end, the present study assessed the predictive relevance for which blindfolding procedure was adopted as recommended by Henseler et al. (2009). It was been suggested by researchers, the values of $\mathrm{Q}^{2}$ must be more than 0 showing the predictive relevance of the study. On the other hand, if the value of $\mathrm{Q}^{2}$ is less than 0 , it shows that there is no predictive relevancy in the model. Table 10 shows the predictive relevance of the present study.

Table 9

Q square

\begin{tabular}{ll}
\hline & $\mathbf{Q}^{\mathbf{2}}(\mathbf{= 1 - S S E} / \mathbf{S S O})$ \\
\hline AI & 0.185 \\
RPI & 0.292 \\
\hline
\end{tabular}

Note: $\mathrm{AI}=$ Airline Image, $\mathrm{RPI}=$ Repurchase Intention

\section{Discussion}

The results of the study have shown that sensory stimuli are important factors for the evaluation of the airline. In the present study, mediating impact of airline image was examined between touch and gustatory stimuli. Moreover, the researcher examined the moderating role of PPF as well. It has been revealed by the findings of the study that touch stimuli were very important for the evaluation of airline services. If the temperature within the airline during travelling is good, leg space is enough, and seats are comfortable; customers will develop positive image in customers' mind. Moreover, their intention to travel through this airline again will be developed. Thus, $\mathrm{H}_{1}$ and $\mathrm{H}_{2}$, proposed in the present study, have been accepted. These results are in line with the findings of Ali et al. (2013) and Yoganathan et al. (2019). On the other hand, food provided to international passengers also have a critical role in creating an image on customers' minds. Additionally, quality of food, taste and variety also develop intention among customers of the airline. Therefore, $\mathrm{H}_{3}$ and $\mathrm{H}_{4}$ proposed in the present study are accepted. The findings of the present study are in line with the findings of Hussain (2018) and Zahari et al. (2011). Furthermore, positive airline image also has a significant impact on repurchase intention as well. Positive perception is basically developed on the basis of past experience due to which willing to repurchase in enhanced positively. Therefore, $\mathrm{H}_{5}$ proposed in the present study is also accepted.

On the other hand, proposed mediating impact of airline image between gustatory stimuli, touch stimuli and repurchase intention is accepted statistically through the findings of the present study, accepting $\mathrm{H}_{6}$ and $\mathrm{H}_{7}$ proposed earlier. These mediating results are in line with the SOR model proposed by Mehrabian and Russel (1974). In the end, findings of the study reveal that price fairness helps in strengthening the relationship of airline image and repurchase intention.

\section{Conclusion and Contribution of the Study}

This is the era of globalization, in which organizations must think out of the box to retain their customers. Retention of customers is necessary for the survival of firms in local as well as international market. Airlines are an important industry in the service sector. They should think beyond traditional marketing strategies to retain their customers. Therefore, they should focus on sensory marketing stimuli's and try to provide a good experience to the customers. Among all five sensory stimuli's, the present study examined the impact of touch and gustatory stimuli on airline image and repurchase intention.

Findings of the study revealed that Pakistan based airline companies namely air blue and PIA, must focus on providing comfort to the customers. They must understand the preferences of the customers in terms of seat selection, temperature, equipment which they can touch and leg space. If these airline operators can provide suitable temperature during the flight which means 
the air conditioning system should be working properly, leg space between seats is comfortable, the material used for the seats is soft and make the traveller feel good, and by using the entertainment system, they feel relaxing airlines will be successfully able to develop a positive perception in the mind of the customer and develop repurchase intention.

The food is provided to airline travellers should be of good quality, it should be delicious and tasty. Moreover, the food provided to the customer must be mouth-watering. In this case, airline travellers will be having a positive experience while travelling through Pakistan based airlines. In case of travelling again on an international route, these passengers will prefer Pakistan based airlines on the basis of their past experience and positive image. In the end, the study confirmed the important role of price in post-purchase behaviour. Customers evaluate the experience in terms of price they paid against these services. If the customer has the perception that the price they are paying against the services, their intention to repurchase will be enhanced.

The present study has helped in bridging a number of gaps. First, the present study has tried to fill the gap of sensory marketing studies in the airline industry, especially in the context of Pakistan. Secondly, the mediating role of airline image under SOR model on the path of sensory marketing and repurchase intention has been examined for the first time in the present study. In the end, the study has examined the moderating role of PPF in the post-purchase theoretical model, as recommended by Ryu and Han (2010). On the other hand, findings of the present study are helpful for the policymakers of Pakistan based airline industry in developing the strategies to retain the customers on their international routes.

\section{References}

Aitamer, G., \& Zhou, Q. (2011). Motives and guidance for the use of sensory marketing in retailing. unpublished Master's dissertation, Karlstad Business School, Sweden.

Ali, F., Omar, R., \& Amin, M. (2013). An examination of the relationships between physical environment, perceived value, image and behavioural Intentions: A SEM approach towards Malaysian resort hotels. Journal of Hotel and Tourism Management, 27(2), 9-26.

Bayraktar, E., Tatoglu, E., Turkyilmaz, A., Delen, D., \& Zaim, S. (2012). Measuring the efficiency of customer satisfaction and loyalty for mobile phone brands with DEA. Expert Systems with Applications, 39(1), 99-106.

Bravo, R., Montaner, T., \& Pina, J. M. (2009). The role of bank image for customers versus non-customers. International Journal of Bank Marketing, 27(4).

Căruntu, A. L., \& Diţoiu, M. C. (2014). The perceptions of hospitality services of a tourism destination. Procedia-Social and Behavioral Sciences, 109, 231-235.

Chang, L.-Y., \& Hung, S.-C. (2013). Adoption and loyalty toward low cost carriers: The case of Taipei-Singapore passengers. Transportation Research Part E: Logistics and Transportation Review, 50, 29-36.

Chin, W. W. (2010). How to write up and report PLS analyses Handbook of partial least squares (pp. 655-690): Springer.

Cohen, J. (1988). Statistical power analysis for the behavioral sciences, 2nd edn. Á/L: Erbaum Press, Hillsdale, NJ, USA.

Cornelissen, J. P. (2006). Making sense of theory construction: Metaphor and disciplined imagination. Organization Studies, 27(11), 1579-1597.

Erciş, A., Ünal, S., Candan, F. B., \& Yıldırım, H. (2012). The effect of brand satisfaction, trust and brand commitment on loyalty and repurchase intentions. Procedia-Social and Behavioral Sciences, 58, 1395-1404.

Erenkol, A. D., \& Merve, A. (2015). Sensory marketing. Journal of Administrative Science Policy Studies, 3, 1-26.

Estalami, H., Maxwell, S., Martín-Consuegra, D., Molina, A., \& Esteban, Á. (2007). An integrated model of price, satisfaction and loyalty: an empirical analysis in the service sector. Journal of Product \& Brand Management, 16(7).

Farrell, A. M., \& Rudd, J. M. (2009). Factor analysis and discriminant validity: A brief review of some practical issues.

Fornell, C., \& Larcker, D. F. (1981). Structural equation models with unobservable variables and measurement error: Algebra and statistics: Sage Publications Sage CA: Los Angeles, CA.

George, D., \& Mallery, M. (2003). Using SPSS for Windows step by step: a simple guide and reference.

Geraldine, O. (2013). Effects of airline service quality on airline image and passengers loyalty: Findings from Arik Air Nigeria passengers. Journal of Hospitality Management and Tourism, 4(2), 19-28.

Hair, J. F., Sarstedt, M., Ringle, C. M., \& Mena, J. A. (2012). An assessment of the use of partial least squares structural equation modeling in marketing research. Journal of the academy of marketing science, 40(3), 414-433.

Hair Jr, J. F., Sarstedt, M., Ringle, C. M., \& Gudergan, S. P. (2017). Advanced issues in partial least squares structural equation modeling: saGe publications.

Henseler, J., Ringle, C. M., \& Sinkovics, R. R. (2009). The use of partial least squares path modeling in international marketing New challenges to international marketing: Emerald Group Publishing Limited.

Hu, H.-H., Kandampully, J., \& Juwaheer, T. D. (2009). Relationships and impacts of service quality, perceived value, customer satisfaction, and image: an empirical study. The service industries journal, 29(2), 111-125.

Hussain, S. (2018). Brand Image and Customer Loyalty Through Sensory Marketing Strategies-A Study on International Fast Food Chain Restaurants.

Jones, T., \& Taylor, S. F. (2007). The conceptual domain of service loyalty: how many dimensions? Journal of Services Marketing, 21(1).

Kashif, M., Zarkada, A., \& Ramayah, T. (2018). The impact of attitude, subjective norms, and perceived behavioural control on managers' intentions to behave ethically. Total Quality Management \& Business Excellence, 29(5-6), 481-501. 
Keller, K. L. (1993). Conceptualizing, measuring, and managing customer-based brand equity. Journal of marketing, 57(1), $1-22$.

Kim, C., Galliers, R. D., Shin, N., Ryoo, J.-H., \& Kim, J. (2012). Factors influencing Internet shopping value and customer repurchase intention. Electronic Commerce Research and Applications, 11(4), 374-387.

Kotler, P., \& Armstrong, G. (2010). Principles of marketing: Pearson education.

Lau, V. (2017). Sensory perceptions of Asian destinations. Critical Tourism Studies Proceedings, 2017(1), 158.

Lindstrom, M. (2005). Broad sensory branding. Journal of Product \& Brand Management, 14(2), 84-87.

Liu, C.-H. S., \& Lee, T. (2016). Service quality and price perception of service: Influence on word-of-mouth and revisit intention. Journal of Air Transport Management, 52, 42-54.

Liu, Y., \& Jang, S. S. (2009). Perceptions of Chinese restaurants in the US: what affects customer satisfaction and behavioral intentions? International Journal of Hospitality Management, 28(3), 338-348.

Loureiro, S. M. C., \& Fialho, A. F. (2017). The role of intrinsic in-flight cues in relationship quality and behavioural intentions: segmentation in less mindful and mindful passengers. Journal of Travel \& Tourism Marketing, 34(7), 948-962.

McCrae, R. R., Kurtz, J. E., Yamagata, S., \& Terracciano, A. (2011). Internal consistency, retest reliability, and their implications for personality scale validity. Personality and Social Psychology Review, 15(1), 28-50.

Mehrabian, A., \& Russel, J. (1974). An approach to environmental psycho- : Cambridge, Mass.: Witt press.

Onyemachi, O., \& Lilian, K.-O. (2012). Analysis of the Determinants of Repurchase Intention of Soap Products of an Agribusiness Firm in Abia State, Nigeria: Citeseer.

Park, J.-W., Robertson, R., \& Wu, C.-L. (2004). The effect of airline service quality on passengers' behavioural intentions: a Korean case study. Journal of Air Transport Management, 10(6), 435-439.

Ryu, K., \& Han, H. (2010). Influence of the quality of food, service, and physical environment on customer satisfaction and behavioral intention in quick-casual restaurants: Moderating role of perceived price. Journal of Hospitality \& Tourism Research, 34(3), 310-329.

Şahin, A., Zehir, C., \& Kitapccedil, H. (2012). The effects of brand experience and service quality on repurchase intention: The role of brand relationship quality. African Journal of Business Management, 6(45), 11190-11201.

Saleem, M. A., Zahra, S., \& Yaseen, A. (2017). Impact of service quality and trust on repurchase intentions-the case of Pakistan airline industry. Asia Pacific Journal of Marketing and Logistics, 29(5).

Sarstedt, M., Ringle, C. M., Henseler, J., \& Hair, J. F. (2014). On the emancipation of PLS-SEM: A commentary on Rigdon (2012). Long range planning, 47(3), 154-160.

Schlomer, G. L., Bauman, S., \& Card, N. A. (2010). Best practices for missing data management in counseling psychology. Journal of Counseling Psychology, 57(1), 1.

Singh, A. K. (2015). Modeling passengers' future behavioral intentions in airline industry using SEM. Journal of Advances in Management Research, 12(2).

Singh, R., \& Khan, I. A. (2012). An approach to increase customer retention and loyalty in B2C world. International Journal of Scientific and Research Publications, 2(6), 1-5.

Spence, C., \& Piqueras-Fiszman, B. (2014). The perfect meal: the multisensory science of food and dining: John Wiley \& Sons.

Suh, M., Moon, H., Han, H., \& Ham, S. (2015). Invisible and intangible, but undeniable: Role of ambient conditions in building hotel guests' loyalty. Journal of Hospitality Marketing \& Management, 24(7), 727-753.

Tabachnick, B. G., Fidell, L. S., \& Ullman, J. B. (2007). Using multivariate statistics (Vol. 5): Pearson Boston, MA.

Wiedmann, K.-P., Labenz, F., Haase, J., \& Hennigs, N. (2018). The power of experiential marketing: exploring the causal relationships among multisensory marketing, brand experience, customer perceived value and brand strength. Journal of Brand Management, 25(2), 101-118.

Yoganathan, V., Osburg, V.-S., \& Akhtar, P. (2019). Sensory stimulation for sensible consumption: Multisensory marketing for e-tailing of ethical brands. Journal of Business Research, 96, 386-396.

Zahari, M., Salleh, N., Kamaruddin, M., \& Kutut, M. (2011). In-flight meals, passengers' level of satisfaction and re-flying intention. World Academy of Science, Engineering and Technology, 60(12), 1353-1360.

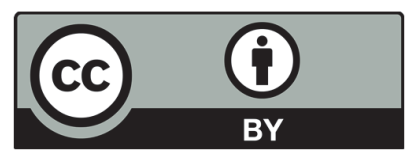

(C) 2021 by the authors; licensee Growing Science, Canada. This is an open access article distributed under the terms and conditions of the Creative Commons Attribution (CC-BY) license (http://creativecommons.org/licenses/by/4.0/). 